\title{
Use of Industrial Coal Waste Materials as Adsorbents for Textile Effluent Remediation
}

\author{
Mohamed H. Mohamed, Marissa Pirlot, Michael K. Danquah, Lee D. Wilson* \\ Department of Chemistry, University of Saskatchewan, Saskatoon, Saskatchewan, Canada \\ Email: *lee.wilson@usask.ca
}

How to cite this paper: Mohamed, M.H., Pirlot, M., Danquah, M.K. and Wilson, L.D. (2017) Use of Industrial Coal Waste Materials as Adsorbents for Textile Effluent Remediation. Jour- nal of Materials Science and Chemical Eng-ineering, 5, 12-24. https://doi.org/10.4236/msce.2017.58002

Received: July 5, 2017

Accepted: August 8, 2017

Published: August 11, 2017

\begin{abstract}
This paper presents experimental study on six carbonaceous industrial waste samples that were obtained from a local industry in Saskatchewan, Canada. Hereafter, the samples are coded as ES1, ES2, ES3, PU, RPS and SS1 and were characterized using IR and ${ }^{13} \mathrm{C}$ solid state NMR spectroscopy, nitrogen porosimetry, TGA, metal leaching analysis using ICP and point-of-zero-charge. Adsorption studies were conducted using two types of adsorptive dye probes (p-nitrophenol, PNP; and methylene blue; $\mathrm{MB}$ ) at pH 4.60 and $\mathrm{pH}$ 7.00.
\end{abstract}

\section{Keywords}

Sorption, Coal, Dye, Nitrophenol, Methylene Blue

\section{Introduction}

Uncontrolled release of effluent from the textile industry is one of the major point sources of water pollution through discharge into aquatic environments [1]. Dyes are the main chemical constituents employed in this industry and decolourization [2] of the effluent or removal of dye species is required [1]. New policies are anticipated that will be enforced to address wastewater treatment on textile industries prior to discharge into aquatic environments [3].

Various techniques have been employed (cf. Table 1 in Ref [4]) for the removal of dyes from textile wastewater effluent. A recent review proposed a combination of adsorption and ozonation techniques as an effective approach [5]. Activated carbon (AC) was shown to be among the most efficient adsorbent materials for the removal of dyes via adsorption-based methods. Properties of AC include its high surface area, enhancement of electrochemical dye oxidation, coagulation, and reductive catalysis of dyes [6] [7]. However, AC is relatively costly in contrast to industrial carbonaceous waste materials, as evidenced by the 
Table 1. Metal analysis using ICP-MS for ES1 material using acid digestion and conventional leaching in water.

\begin{tabular}{|c|c|c|c|}
\hline $\begin{array}{c}\text { Mineral } \\
\text { Containing Phase }\end{array}$ & Level & Acid Digested & Leaching in water \\
\hline Aluminium & $\mathrm{mg} / \mathrm{L}$ & 33 & 1.2 \\
\hline Antimony & $\mathrm{mg} / \mathrm{L}$ & $<0.02$ & $<0.02$ \\
\hline Arsenic & $\mu \mathrm{g} / \mathrm{L}$ & $<10$ & $<10$ \\
\hline Barium & $\mathrm{mg} / \mathrm{L}$ & 7.1 & 0.17 \\
\hline Beryllium & $\mathrm{mg} / \mathrm{L}$ & $<0.01$ & $<0.01$ \\
\hline Boron & $\mathrm{mg} / \mathrm{L}$ & 5.0 & 4.0 \\
\hline Cadmium & $\mathrm{mg} / \mathrm{L}$ & 0.001 & $<0.001$ \\
\hline Chromium & $\mathrm{mg} / \mathrm{L}$ & $<0.05$ & $<0.05$ \\
\hline Cobalt & $\mathrm{mg} / \mathrm{L}$ & $<0.01$ & $<0.01$ \\
\hline Copper & $\mathrm{mg} / \mathrm{L}$ & $<0.02$ & $<0.02$ \\
\hline Iron & $\mathrm{mg} / \mathrm{L}$ & 22 & $<0.05$ \\
\hline Lead & $\mathrm{mg} / \mathrm{L}$ & 0.02 & $<0.01$ \\
\hline Manganese & $\mathrm{mg} / \mathrm{L}$ & 0.12 & $<0.05$ \\
\hline Molybdenum & $\mathrm{mg} / \mathrm{L}$ & $<0.01$ & $<0.01$ \\
\hline Nickel & $\mathrm{mg} / \mathrm{L}$ & $<0.01$ & $<0.01$ \\
\hline Selenium & $\mathrm{mg} / \mathrm{L}$ & $<0.01$ & $<0.01$ \\
\hline Silver & $\mathrm{mg} / \mathrm{L}$ & $<0.005$ & $<0.005$ \\
\hline Strontium & $\mathrm{mg} / \mathrm{L}$ & 3.5 & 0.1 \\
\hline Thallium & $\mathrm{mg} / \mathrm{L}$ & $<0.02$ & $<0.02$ \\
\hline Tin & $\mathrm{mg} / \mathrm{L}$ & $<0.01$ & $<0.01$ \\
\hline Titanium & $\mathrm{mg} / \mathrm{L}$ & 0.86 & $<0.02$ \\
\hline Uranium & $\mu \mathrm{g} / \mathrm{L}$ & $<10$ & $<10$ \\
\hline Vanadium & $\mathrm{mg} / \mathrm{L}$ & 0.04 & $<0.01$ \\
\hline Zinc & $\mathrm{mg} / \mathrm{L}$ & 44 & 0.35 \\
\hline
\end{tabular}

use of such adsorbent materials for the removal of dyes from aqueous media with variable efficacy [8] [9] [10] [11] [12].

The objectives of this research work relate to the characterization and utilization of carbonaceous industrial waste samples obtained from local industry (SaskPower; principal electric utility in Saskatchewan, Canada) and to study their utility as adsorbents for the removal of model dye systems ( $p$-nitrophenol (PNP) and methylene blue (MB)) to simulate wastewater effluent in contaminated aquatic environments.

\section{Experimental}

\subsection{Materials}

Six coal waste samples labelled as ES1, ES2, ES3, PU, RPS and SS1, were obtained 
from a local industry (SaskPower) in Saskatchewan, Canada. The samples were used without any modification/purification. Methylene blue (MB), p-nitrophenol (PNP) and potassium bromide were obtained from Sigma-Aldrich Canada Ltd. Nitric acid and hydrochloric acid were purchased from EMD USA. All chemicals were used as received without further purification unless stated otherwise.

\subsection{Characterization}

Thermogravimetric analysis (TGA): Thermal weight loss profiles of the samples were analyzed using a TA Instruments Q50 TGA system at a heating rate of $5^{\circ} \mathrm{C} \mathrm{min}^{-1}$ to a maximum temperature of $900^{\circ} \mathrm{C}$ using nitrogen as the carrier gas. The thermal stability of the respective components of the materials are reported as first derivative plots of weight/temperature $\left(\% /{ }^{\circ} \mathrm{C}\right)$ against temperature $\left({ }^{\circ} \mathrm{C}\right)$.

Diffuse Reflectance Infrared Fourier Transform Spectra (DRIFTS): Diffuse reflectance infrared spectroscopy (DRIFTS) results were obtained using a BioRAD FTS-40 spectrophotometer at $295 \mathrm{~K}$ over a $400-4000 \mathrm{~cm}^{-1}$ spectral range. Powdered samples were mixed with pure spectroscopic grade $\mathrm{KBr}$ in a 1:100 wt.\% ratio followed by grinding in a small mortar and pestle. Multiple scans were recorded and corrected relative to a background of pure $\mathrm{KBr}$.

${ }^{13} \mathrm{C}$ Solids NMR Spectroscopy: The NMR experiments were performed using a Bruker AVANCE III HD spectrometer operating at $125.77 \mathrm{MHz}\left({ }^{1} \mathrm{H}\right.$ frequency at $500.23 \mathrm{MHz}$ ) with a $4 \mathrm{~mm}$ DOTY CP-MAS probe. The ${ }^{13} \mathrm{C} \mathrm{CP} / \mathrm{TOSS}$ (Cross Polarization with Total Suppression of Spinning Sidebands) spectra were obtained with a spinning speed of $6 \mathrm{kHz}$ with a ${ }^{1} \mathrm{H} 90^{\circ}$ pulse of $3.5 \mu \mathrm{s}, 1.0 \mathrm{~ms}$ contact time, and a ramp pulse on the ${ }^{1} \mathrm{H}$ channel. Acquisition of spectra utilized multiple scans (1024 - 2048) with a recycle delay of $2 \mathrm{~s}$. All spectra were recorded using $71 \mathrm{kHz}$ SPINAL-64 decoupling sequence and chemical shifts were referenced to adamantane (38.48 ppm).

Porosimetry: Nitrogen adsorption results were obtained using a Micromeritics ASAP 2020 (Norcross, GA) to evaluate the surface area and pore structure properties with an estimated accuracy of $\pm 5 \%$. Approximately, $1 \mathrm{~g}$ of the sample was degassed at an evacuation rate of $5 \mathrm{~mm} \mathrm{Hg} / \mathrm{s}$ in the sample chamber until the outgas rate became stabilized $(<10 \mathrm{mmHg} / \mathrm{min})$. The degas temperature for the samples was maintained $\sim 90^{\circ} \mathrm{C}$ until the degas rate was below $10 \mu \mathrm{mHg} / \mathrm{min}$. Alumina, and silica-alumina standards (Micromeretics) were used to check the calibration of the instrumental parameters for low and high surface area materials, respectively. The BET surface area was calculated from the adsorption isotherm where $0.162 \mathrm{~nm}^{2}$ was used for the surface area for gaseous molecular nitrogen [13] [14]. The micropore surface area was obtained using a t-plot (de Boer method) [15]. The Barrett-Joyner-Halenda (BJH) method was used to estimate the pore volume and pore diameter from the adsorption isotherm [16]. The $\mathrm{BJH}$ method uses the Kelvin equation and the assumption of slit-shaped pores [13] [14]. 
Inductively coupled plasma-optical emission spectrometry (ICP-OES): The samples were analyzed using an Agilent 7900 ICP-MS (SOP number: Chm522) which followed a Standard Method for the Examination of Water and Wastewater, Part 3125, APHA-AWWA-WEF; without modification.

Point-of-Zero-Charge (PZC): The PZC for ES1 was determined according to a method described in a previous report [17]. A stock solution of $\mathrm{NaCl}(0.01 \mathrm{M})$ was prepared and $25 \mathrm{~mL}$ portions were transferred into $125 \mathrm{~mL}$ Erlenmeyer flasks. The $\mathrm{pH}$ of the solutions was adjusted between 2 and 10 using $\mathrm{NaOH} / \mathrm{HCl}$ such that each flask had a different $\mathrm{pH}$ value. Approximately $100 \mathrm{mg}$ of ES1 was added to each solution and was equilibrated for $48 \mathrm{~h}$ before the final $\mathrm{pH}$ was measured. A graph of final $\mathrm{pH}$ vs initial $\mathrm{pH}$ was plotted and the intersection point was recorded as the $\mathrm{pH}$ for point of zero charge $\left(\mathrm{pH}_{\mathrm{zpc}}\right)$.

\subsection{Sorption}

To determine the adsorption capacity of the carbonaceous materials with two types of dyes at equilibrium conditions, various initial concentrations $\left(\mathrm{C}_{0}\right)$ of $\mathrm{PNP}(\mathrm{pH} 4.60)$ and $\mathrm{MB}(\mathrm{pH} 7.0)$ were prepared in the range $0.5-30 \mathrm{mM}$ and $0.05-3.0 \mathrm{mM}$, respectively. Approximately, $10 \mathrm{mg}$ of adsorbent was mixed with $7 \mathrm{~mL}$ of $\mathrm{MB}$ dye solution at variable concentration and the mixtures were equilibrated on a horizontal shaker (SCILOGEX SK-O330-Pro) in batch mode for $24 \mathrm{~h}$. The supernatant solutions were analyzed by measuring UV-Vis absorbance (Varian Cary 100) at $317 \mathrm{~nm}$ (PNP) and $664 \mathrm{~nm}$ (MB) to determine the dye concentration after adsorption $\left(\mathrm{C}_{\mathrm{e}}\right)$. Adsorption isotherms were generated using Equation (1) and evaluated by the Sips isotherm model with Equation (2) $q_{m}$ (mmol. $\left.\mathrm{g}^{-1}\right)$ is the monolayer adsorption capacity at equilibrium, $K_{s}$ $\left(\mathrm{L} \cdot \mathrm{mmol}^{-1}\right)$ is Sips isotherm constant related to energy of adsorption and $n_{s}$ is the surface heterogeneity parameter.

$$
\begin{gathered}
q_{e}=\frac{\left(\mathrm{C}_{0}-\mathrm{Ce}_{\mathrm{e}}\right) \times \mathrm{V}}{\mathrm{m}} \\
q_{e}=\frac{q_{m} K_{S} C_{e}^{n_{s}}}{1+K_{S} C_{e}^{n_{s}}}
\end{gathered}
$$

\section{Results and Discussion}

Several factors related to the physicochemical properties of an adsorbent contribute to its effectiveness as an adsorbent which relate to textural properties and surface chemistry [18] [19]. Therefore, several complementary methods were employed to test the carbonaceous industrial materials as potential adsorbents with model organic dyes (MB and PNP).

\subsection{Characterization}

TGA is a suitable method for materials characterization since well resolved thermal events can provide insight on the composition of components in composite materials such as supported materials [20]. Mohamed et al. illustrated the 
utility of TGA for estimating the composition of cross-linker and polysaccharide in cross-linked polymer materials [21]. Figure 1 illustrates the TGA results for the various carbonaceous materials where three thermal events with weight loss profiles are observed across the temperature range. The first event below $100^{\circ} \mathrm{C}$ relates to desorption of water and/or vapours since such types of coal materials are known to be hygroscopic [22]. The second event between $200^{\circ} \mathrm{C}-600^{\circ} \mathrm{C}$ is due to the release of volatile matter such as light hydrocarbons and/or aliphatic components, while the third event above $600^{\circ} \mathrm{C}$ is attributed to decomposition of graphitic components and/or heavier hydrocarbons and non-condensable gases [23]. Each of the six materials display unique thermal profiles that indicate variable composition and thermal stability of the components. The presence of heteroatoms and trace metals are anticipated to contribute to variable thermal stability of the carbonaceous framework, as indicated in studies of polyaniline and iron oxide supported activated carbon [20] [24].

Figure 2 shows the normalized IR spectra that reveals the relative differences in functional groups between the materials with variable composition. All materials exhibit $-\mathrm{OH}\left(3800-3000 \mathrm{~cm}^{-1}\right)$, aliphatic hydrocarbons; $-\mathrm{CH}_{3}$ and $\mathrm{CH}_{2}$ (3000 - $\left.2800 \mathrm{~cm}^{-1}, 1390 \mathrm{~cm}^{-1}\right)$, carbonyl-bearing group $\left(\sim 1700 \mathrm{~cm}^{-1}\right)$, aromatics, poly- and/or heteroatom-based aromatic rings $\left(\sim 1595 \mathrm{~cm}^{-1}, 900-700 \mathrm{~cm}^{-1}\right)$, vibrational frequencies of oxygen in C-O-R $\left(1145-950 \mathrm{~cm}^{-1}\right)$ and minerals such as aluminum, iron, or zinc according to spectral signatures in the fingerprint region $\left(600-500 \mathrm{~cm}^{-1}\right)$ [25] [26] [27] [28]. The aforementioned functional groups are dissimilar for each carbonaceous material and in some cases, heteroatom signatures are absent like C-O-R. Spectral evidence of mineral species are not apparent for ES3 and SS1.

To confirm the presence of mineral phases from the above IR analysis, selected samples were examined by subjecting the carbonaceous materials to acid digestion and subsequent analysis of metals using ICP MS. The ES1 sample was



Figure 1. Differential thermal analysis (DTA) plots (weight loss $/{ }^{\circ} \mathrm{C} v s$ temperature) of TGA data for the industrial carbonaceous materials. 


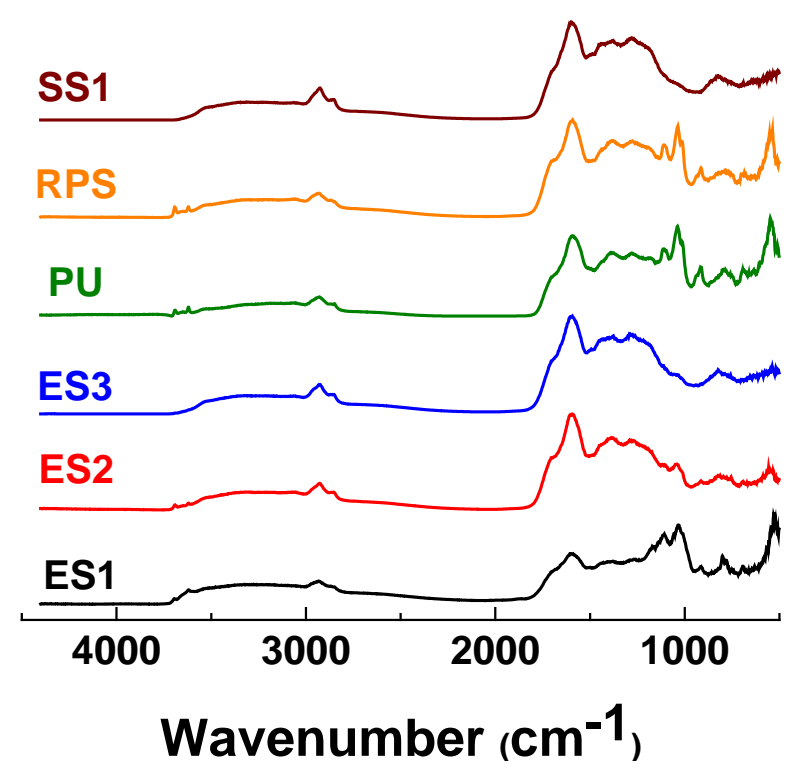

Figure 2. Normalized DRIFT spectra of the industrial carbonaceous materials.

analyzed using this method of acid digestion in water ( $c f$. Table 1), where the ICP results reveal that the material contains various mineral phases. The main contributions relate to aluminum, barium, boron, iron, strontium, titanium and zinc. Based on the leaching test, aluminum (1.2 ppm), boron (4 ppm) and zinc (0.35 ppm) appear to be the main mineral species leached into water by acid digestion. In all cases, there appears to be greater leaching from the carbonaceous solid using acid digestion over water and this may relate to the present of amorphous domains of the carbonaceous phase that undergoes greater dissolution over water, as reported for activated carbon materials [19].

Figure 3 reveals the ${ }^{13} \mathrm{C}$ NMR spectral results for solids obtained under crosspolarization $(\mathrm{CP})$ and magic angle spinning (MAS) conditions for the carbonaceous materials. The ${ }^{13} \mathrm{C}$ signatures of the industrial solids show evidence of aliphatic $(0-65 \mathrm{ppm})$ and aromatic (95- $165 \mathrm{ppm})$ carbon atoms [29] [30], in agreement with the above IR results. Peak area analyses for the two types of hydrocarbons (cf. Table 2) reveal that ${ }^{13} \mathrm{C}$ aromatic content exceeds the aliphatic contributions for each of the industrial materials. The carbonaceous solids reveal the presence of carbon attached to heteroatoms as evidenced by a carbonyl signature (C-O-R; $\sim 178 \mathrm{ppm}$ ), along with the ${ }^{13} \mathrm{C}$ signature ca. $60-90 \mathrm{ppm}$, in support of the presence of $\mathrm{C}-\mathrm{O}$ groups. The unique structure of the carbonaceous materials is also supported by the ${ }^{13} \mathrm{C}$ signatures of the framework according to variable intensity and chemical shifts in Figure 3. The ${ }^{13} \mathrm{C}$ NMR results are further supported by the TGA and DRIFTS results above.

The nitrogen adsorption-desorption isotherms for the carbonaceous materials are illustrated in Figure 4. Each of the various materials reveal hysteresis loops that close near a relative pressure $\left(\mathrm{p} / \mathrm{p}^{\circ} \approx 0.4\right)$ that is indicative of mesoporous character. The magnitude of nitrogen uptake is relatively low which suggests low 


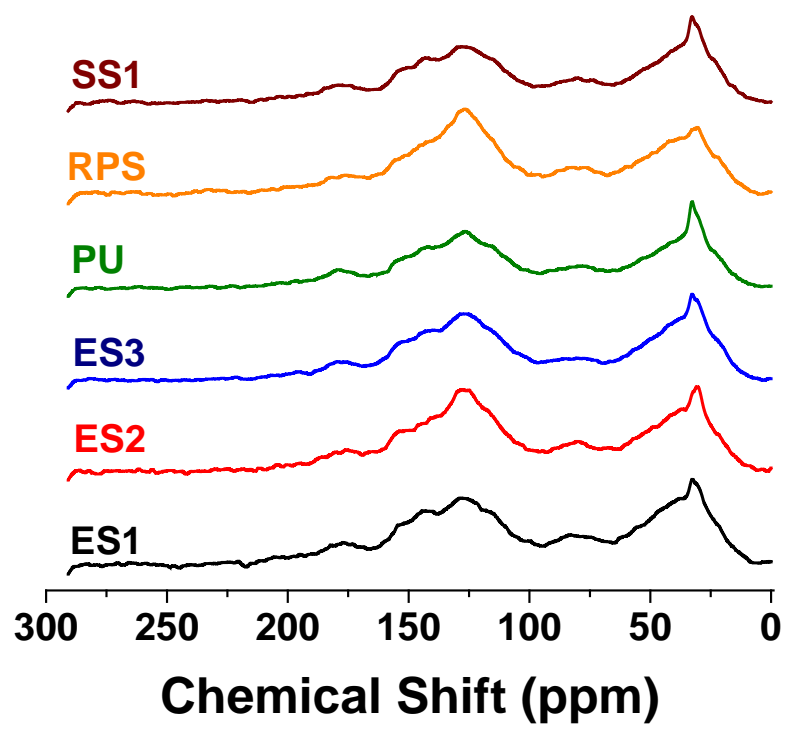

Figure 3. Normalized solid state ${ }^{13} \mathrm{C}$ NMR spectra of the carbonaceous materials.


Figure 4. Nitrogen adsorption-desorption isotherm for carbonaceous materials at $77 \mathrm{~K}$.

Table 2. ${ }^{13} \mathrm{C}$ NMR peak areas of aliphatic $(0-65 \mathrm{ppm})$ and aromatic region $(95-165$ ppm) for the carbonaceous materials.

\begin{tabular}{lllllll}
\hline & ES1 & ES2 & ES3 & PU & RPS & SS1 \\
\hline Aliphatic & 32.0 & 30.1 & 29.7 & 25.8 & 28.4 & 28.0 \\
Aromatic & 38.0 & 41.1 & 36.4 & 30.2 & 40.6 & 31.9 \\
\hline
\end{tabular}

pore volume while the isotherm shape indicates a type IV isotherm, in agreement with the nature of mesoporous adsorbents according to IUPAC [31] [32]. The variable $\mathrm{P} / \mathrm{P}^{\circ}$ values $(0.42-0.75)$ for the hysteresis loops infer that there are differences in evaporation versus condensation within the pores [33]. The capillary condensation occurs within the mesopore domains. The surface area (SA) of 
the carbonaceous materials is generally low and ranges between $1.67-4.27 \mathrm{~m}^{2} / \mathrm{g}$ (cf. Table 3) while the average pore width ranges between 97.2 - $116 \AA$ and confirms that the materials are mesoporous with low pore volume. Tabulated values from the BET analysis are given in Table $\mathbf{3}$ for the various carbonaceous materials.

Determination of the point where the net surface charge of a material is zero is important for an understanding of the electrostatic interactions at material surfaces, especially for charged species. At $\mathrm{pH}>\mathrm{pH}_{\mathrm{zpc}}$, there is adsorption of positively charged ions such as $\mathrm{H}^{+}$ions or other cations due to ionization effects at the material surface due to deprotonation. The opposite is true when the $\mathrm{pH}<$ $\mathrm{pH}_{\mathrm{zpc}}$, where the adsorption of $\mathrm{OH}^{-}$ions and/or other anion species occurs due to the build-up of positive charge. The results obtained in Figure 5 reveal that the $\mathrm{pH}_{\mathrm{zpc}}$ of $\mathrm{ES} 1$ is ca. 6.40. This implies that coal materials may be more suitable for the uptake of cation species such as $\mathrm{MB}$, when $\mathrm{pH}>\mathrm{pH}_{\mathrm{pzc}}$. This occurs near ambient $\mathrm{pH}$ conditions $(\mathrm{pH} \sim 7)$. Thus, various model dyes were examined to probe the adsorption affinity of neutral and cationic dyes with the various carbonaceous materials to evaluate their efficacy as potential adsorbents. The following dyes, $\mathrm{PNP}$ ( $\mathrm{pH} 4.60$ ) and $\mathrm{MB}$ ( $\mathrm{pH} 7.00$ ), were studied at variable $\mathrm{pH}$ conditions to understand the role of surface charge effects.

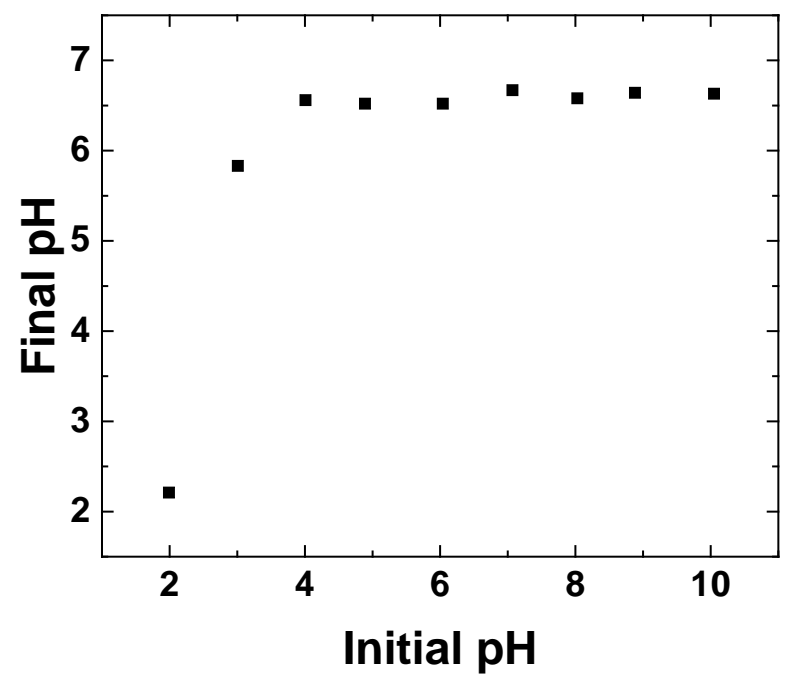

Figure 5. Point of zero charge for ES1.

Table 3. BET parameters obtained from adsorption of nitrogen for carbonaceous materials at $77 \mathrm{~K}$.

\begin{tabular}{ccccccc}
\hline & ES1 & ES2 & ES3 & PU & RPS & SS1 \\
\hline BET Surface Area $\left(\mathrm{SA} ; \mathrm{m}^{2} / \mathrm{g}\right)$ & 3.55 & 4.27 & 2.03 & 4.21 & 2.99 & 1.67 \\
Adsorption average pore width $(\AA)$ & 97.2 & 101 & 101 & 108 & 116 & 116 \\
\hline
\end{tabular}

\subsection{Sorption}

Figure 6 and Figure 7 illustrate adsorption isotherms of PNP at $\mathrm{pH} 4.60$ and $\mathrm{MB}$ at $\mathrm{pH} 7.00$ with the carbonaceous materials. It should be noted that PNP 


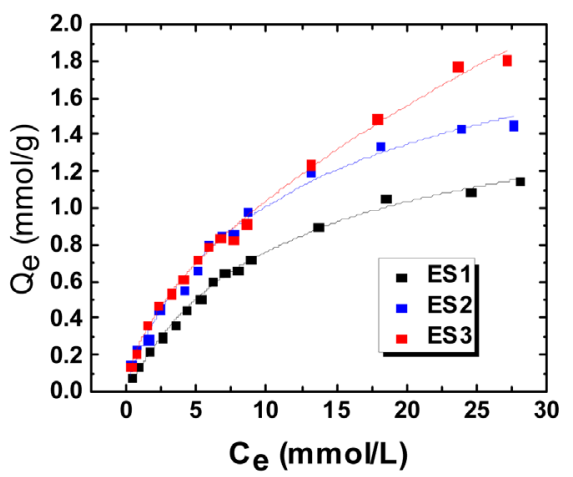

(a)

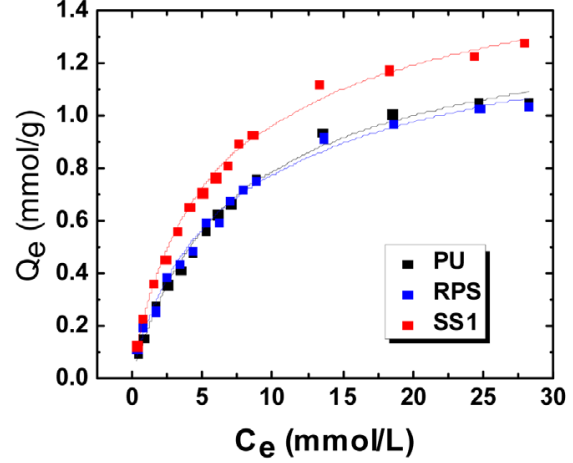

(b)

Figure 6. Sorption of PNP at pH 4.60 and $295 \mathrm{~K}$ using the coal materials.

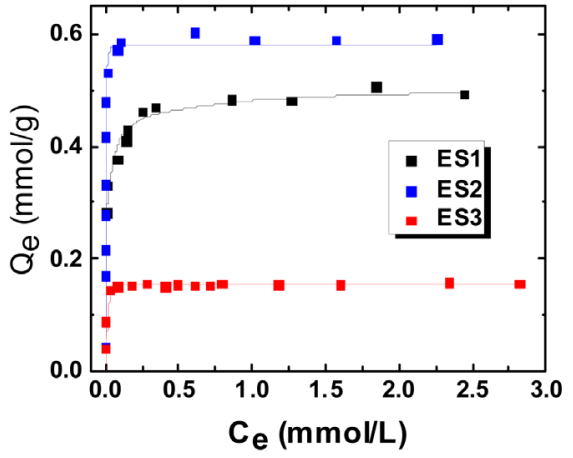

(a)

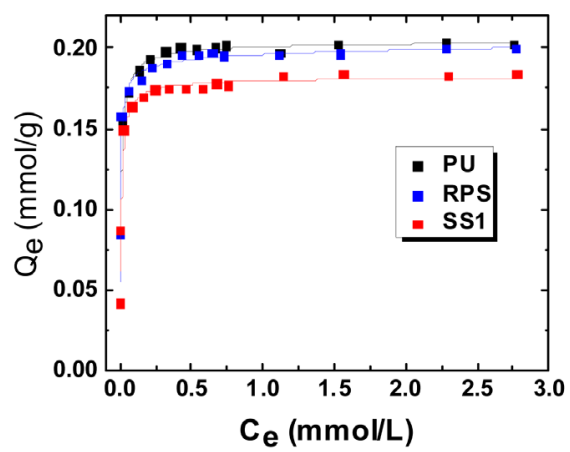

(b)

Figure 7. Sorption of $\mathrm{MB}$ at $\mathrm{pH} 7$ and $295 \mathrm{~K}$ using carbonaceous materials

exists in its non-ionized form since the working $\mathrm{pH}$ condition lies below the $\mathrm{pK}_{\mathrm{a}}$ for this dye $\left(\mathrm{pK}_{\mathrm{a}}=7.1\right)$ [19]. The isotherms were fit using the Sips model. In the case of PNP (cf. Figure 6(a), Figure 6(b)), the value of $\mathrm{Q}_{\mathrm{m}}(c f$. Table 4) was found to decrease in the following order $\left(\mathrm{Q}_{\mathrm{m}}\right.$ in parentheses; mmol/g): ES3 (3.12) > ES2 (2.27) > SS1 (1.68) > ES1 (1.60) > RPS (1.43) > PU (1.39). The trend for their respective adsorption affinity constant $\left(\mathrm{K}_{\mathrm{s}}\right)$ did not appear to correlate with the adsorption capacity, indicating that the role of variable surface chemistry may relate to the presence of heteroatom or metal composition of the carbon framework. The existence of such Lewis acid and base sites could account for the variable dye uptake at the binding sites for the carbonaceous materials. The $\mathrm{K}_{\mathrm{s}}$ values ( $c f$. Table 4$)$ decrease in the following order $\left(\mathrm{K}_{s}\right.$ in parentheses; $\left.\mathrm{M}^{-1}\right)$ : SS1 (146) $>$ PU (135) > RPS (125) > ES1 (92.3) > ES2 (79.3) > ES3 (63.0).

In the case of $\mathrm{MB}$ adsorption with the carbonaceous materials (cf. Figure 7(a), Figure 7(b)), the isotherms were shown to reach saturation ca. $0.10-0.20$ $\mathrm{mM}$ with a sharp rise in the uptake. This trend indicates a high adsorption affinity of the carbonaceous materials for this cation dye species. Figure 8 shows decolourization of MB with ES2 from the isotherm in Figure 7(a). The $Q_{m}$ values (cf. Table 4) were found to decrease in the following order $\left(\mathrm{Q}_{\mathrm{m}}\right.$ in parentheses; $\mathrm{mmol} / \mathrm{g})$ : $\operatorname{ES} 2(0.583)>\operatorname{ES} 1(0.521)>\operatorname{RPS}(0.215)>\mathrm{PU}(0.206)>\mathrm{SS} 1(0.183)>$ 


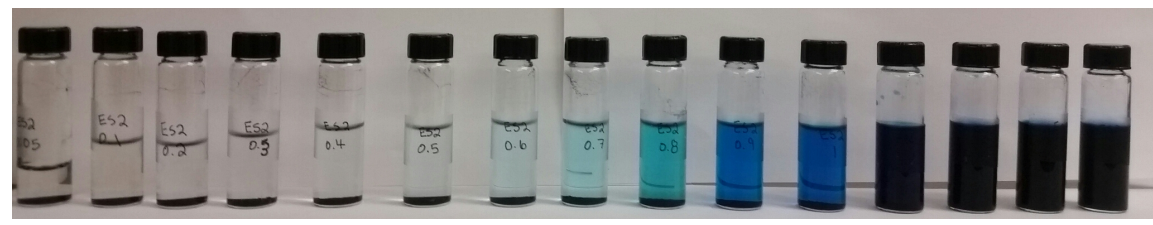

Figure 8. Sorption of MB using ES2.

Table 4. $\mathrm{Q}_{\mathrm{m}}$ and $\mathrm{K}_{\mathrm{s}}$ values obtained for PNP ( $\mathrm{pH}$ 4.60) and $\mathrm{MB}(\mathrm{pH} 7.00)$ using Sips isotherm adsorption model at $295 \mathrm{~K}$.

\begin{tabular}{cccccccc}
\hline & & ES1 & ES2 & ES3 & PU & RPS & SS1 \\
\hline \multirow{2}{*}{ PNP } & $\mathrm{Q}_{\mathrm{m}}(\mathrm{mmol} / \mathrm{g})$ & 1.6 & 2.27 & 3.12 & 1.39 & 1.43 & 1.68 \\
& $K_{s}\left(\mathrm{M}^{-1}\right)$ & 92.8 & 79.3 & 63 & 135 & 125 & 146 \\
\multirow{2}{*}{$\mathrm{MB}$} & $\mathrm{Q}_{\mathrm{m}}\left(\mathrm{mmol}^{\mathrm{g}}\right)$ & 0.521 & 0.583 & 0.155 & 0.206 & 0.215 & 0.183 \\
& $K_{S}\left(\mathrm{mM}^{-1}\right)$ & 162 & 776 & 100 & 307 & 899 & 361 \\
\hline
\end{tabular}

ES3 (0.155). Similar to PNP, the trend for their respective adsorption affinity constant did not correlate to the adsorption capacity. The $\mathrm{K}_{s}$ values (cf. Table 4) decrease in the following order $\left(\mathrm{K}_{\mathrm{s}}\right.$ in parentheses; $\left.\mathrm{mM}^{-1}\right)$ : RPS (899) > ES2 (776) $>$ SS1 (361) > PU (307) > ES1 (162) > ES3 (100). The adsorption capacity of MB with the carbonaceous materials herein relative to other related materials [34] are of comparable magnitude $\left(\approx 10^{2} \mathrm{mg} / \mathrm{g}\right)$. The greater overall uptake of $\mathrm{MB}$ over PNP is indicative of the presence of Lewis base sites on the surface of the carbon framework, in agreement with the IR and NMR spectral results above. In contrast to commercial activated carbon, the carbonaceous industrial wastes reported herein show promise as adsorbents for neutral dyes and cationic species. The uptake of PNP in its ionized state was comparatively low for $\mathrm{pH}$ conditions above the $\mathrm{pK}_{\mathrm{a}}$ value for PNP (results not shown) which provides further evidence that Lewis base sites are present on the sorbent surface. The industrial carbonaceous waste materials reported herein are markedly less expensive relative to commercial activated carbon. The limited need of further activation or modification of such adsorbents for removal of aromatic dyes from wastewater effluent illustrates their potential utility and valorization as alternative sorbent materials.

\section{Conclusion}

Several types of carbonaceous waste materials from SaskPower were structurally characterized and their adsorption properties with PNP and MB was determined. Variable uptake and binding affinity of a neutral phenolic dye (PNP) and a cationic dye $(\mathrm{MB})$ were observed at equilibrium conditions. The difference in adsorption capacity was related mainly to differences in the surface chemistry of the materials due to the presence of heteroatoms or mineral phases on the carbon framework surface sites. This work demonstrates the utility of such industrial carbonaceous waste as an alternative low cost adsorbent material for the controlled remediation of wastewater effluents containing dye-based contaminants. 
We anticipate that such materials will be suitable for applications relevant to textile and chemical manufacturing industry for remediation of wastewater effluent.

\section{Acknowledgements}

The authors are grateful to the University of Saskatchewan for the USRA award to M. Pirlot and the gift of the industrial carbonaceous materials provided by Dr. Emmanuel Quagraine of SaskPower (Estevan, SK.) for this research study. Dexu Kong is acknowledged for technical assistance with metal content determination using ICP-MS analyses.

\section{References}

[1] Khan, S. and Malik, A. (2014) Environmental and Health Effects of Textile Industry Wastewater. In: Malik, A., Grohmann, E. and Akhtar, R., Eds., Environmental Deterioration and Human Health: Natural and Anthropogenic Determinants, Springer Netherlands, Dordrecht, 55-71. https://doi.org/10.1007/978-94-007-7890-0_4

[2] Yeh, R.Y.-L. and Thomas, A. (1995) Color Difference Measurement and Color Removal from Dye Wastewaters Using Different Adsorbents. Journal of Chemical Technology \& Biotechnology, 63, 55-59. https://doi.org/10.1002/jctb.280630108

[3] O’Neill, C., Hawkes, F.R., Hawkes, D.L., Lourenço, N.D., Pinheiro, H.M. and Delée, W. (1999) Colour in Textile Effluents-Sources, Measurement, Discharge Consents and Simulation: A Review. Journal of Chemical Technology \& Biotechnology, 74, 1009-1018.

https://doi.org/10.1002/(SICI)1097-4660(199911)74:11<1009::AID-JCTB153>3.0.C $\mathrm{O} ; 2-\mathrm{N}$

[4] Robinson, T., McMullan, G., Marchant, R. and Nigam, P. (2001) Remediation of Dyes in Textile Effluent: A Critical Review on Current Treatment Technologies with a Proposed Alternative. Bioresource Technology, 77, 247-255. https://doi.org/10.1016/S0960-8524(00)00080-8

[5] Khamparia, S. and Jaspal, D.K. (2017) Adsorption in Combination with Ozonation for the Treatment of Textile Waste Water: A Critical Review. Frontiers of Environmental Science \& Engineering, 11, 8. https://doi.org/10.1007/s11783-017-0899-5

[6] Mezohegyi, G., van der Zee, F. P., Font, J., Fortuny, A. and Fabregat, A. (2012) Towards Advanced Aqueous Dye Removal Processes: A Short Review on the Versatile Role of Activated Carbon. Journal of Environmental Management, 102, 148-164. https://doi.org/10.1016/j.jenvman.2012.02.021

[7] Ahmad, A., Mohd-Setapar, S.H., Chuong, C.S., Khatoon, A., Wani, W.A., Kumar, R. and Rafatullah, M. (2015) Recent Advances in New Generation Dye Removal Technologies: Novel Search for Approaches to Reprocess Wastewater. RSC Advances, 5, 30801-30818. https://doi.org/10.1039/C4RA16959J

[8] Ahmaruzzaman, M. (2011) Industrial Wastes as Low-Cost Potential Adsorbents for the Treatment of Wastewater Laden with Heavy Metals. Advances in Colloid and Interface Science, 166, 36-59. https://doi.org/10.1016/j.cis.2011.04.005

[9] Jain, A.K., Gupta, V.K., Bhatnagar, A. and Suhas. (2003) Utilization of Industrial Waste Products as Adsorbents for the Removal of Dyes. Journal of Hazardous Materials, 101, 31-42. https://doi.org/10.1016/S0304-3894(03)00146-8

[10] Gupta, V.K. and Suhas. (2009) Application of Low-Cost Adsorbents for Dye Removal-A Review. Journal of Environmental Management, 90, 2313-2342.

https://doi.org/10.1016/j.jenvman.2008.11.017 
[11] Hsu, T.C. (2008) Adsorption of an Acid Dye onto Coal Fly Ash. Fuel, 87, 30403045. https://doi.org/10.1016/j.fuel.2008.03.026

[12] Sanghi, R. and Verma, P. (2013) Decolorisation of Aqueous Dye Solutions by LowCost Adsorbents: A Review. Coloration Technology, 129, 85-108. https://doi.org/10.1111/cote.12019

[13] Allen, T. (1997) Particle Size Measurement: Surface Area and Pore Size Determination. Chapman \& Hall, London, UK, 2-6 Boundary Row.

[14] Sing, K. (2001) The Use of Nitrogen Adsorption for the Characterisation of Porous Materials. Colloids and Surfaces A: Physicochemical and Engineering Aspects, 187188, 3-9. https://doi.org/10.1016/S0927-7757(01)00612-4

[15] Broekhoff, J.C.P. and De Boer, J.H. (1968) Studies on Pore Systems in Catalysts: XI. Pore Distribution Calculations from the Adsorption Branch of a Nitrogen Adsorption Isotherm in the Case of "Ink-Bottle" Type Pores. Journal of Catalysis, 10, 153 165. https://doi.org/10.1016/0021-9517(68)90168-1

[16] Barrett, E.P., Joyner, L.G. and Halenda, P.P. (1951) The Determination of Pore Volume and Area Distributions in Porous Substances. I. Computations from Nitrogen Isotherms. Journal of the American Chemical Society, 73, 373-380. https://doi.org/10.1021/ja01145a126

[17] Singh, J., Mishra, N.S., Uma, Banerjee, S. and Sharma, Y.C. (2011) Comparative Studies of Physical Characteristics of Raw and Modified Sawdust for Their Use as Adsorbents for Removal of Acid Dye. BioResources, 6, 2732-2743.

http://ojs.cnr.ncsu.edu/index.php/BioRes/article/view/BioRes_06_3_2732_Com-par _Phys_Char_Sawdust_Remov_Acid_Dye/1033

[18] Kwon, J.H., Wilson, L.D. and Sammynaiken, R. (2015) Sorptive Uptake of Selenium with Magnetite and Its Supported Materials onto Activated Carbon. Journal of Colloid and Interface Science, 457, 388-397. https://doi.org/10.1016/j.jcis.2015.07.013

[19] Kwon, J.H. and Wilson, L.D. (2010) Surface-Modified Activated Carbon with $\beta$-Cyclodextrin-Part II. Adsorption Properties. Journal of Environmental Science and Health, Part A, 45, 1793-1803. https://doi.org/10.1080/10934529.2010.513292

[20] Kwon, J.H., Wilson, L.D. and Sammynaiken, R. (2014) Synthesis and Characterization of Magnetite and Activated Carbon Binary Composites. Synthetic Metals, 197, 8-17. https://doi.org/10.1016/j.synthmet.2014.08.010

[21] Mohamed, M.H., Wilson, L.D. and Headley, J.V. (2011) Design and Characterization of Novel $\beta$-Cyclodextrin Based Copolymer Materials. Carbohydrate Research, 346, 219-229. https://doi.org/10.1016/j.carres.2010.11.022

[22] Hess, F.L. and Schaller, W.T. (1914) Colorado Ferberite and the Wolframite Series. U.S. Government Printing Office. https://doi.org/10.5962/bhl.title.45600

[23] Ishak, M.A.M., Hassan, S.N.A.M., Ali, S.N., Abdullah, M.F., Ani, A.Y., Kasim, N.N., Jawad, A.H., Ismail, W.I.N.W. and Ismail, K. (2015). Overview of Obtaining Alternative Fuels in the Coliquefaction Processes with Biomass and Coal in Malaysia. In: Biernat, K., Ed., Biofuels—Status and Perspective, InTech, Rijeka, p. Ch. 09. https://doi.org/10.5772/59362

[24] Mohamed, M.H., Dolatkhah, A., Aboumourad, T., Dehabadi, L. and Wilson, L.D. (2015) Investigation of Templated and Supported Polyaniline Adsorbent Materials. RSC Advances, 5, 6976-6984. https://doi.org/10.1039/C4RA07412B

[25] Ding, M.J., Du, L.Z. and Wei, X.Y. (2011) CS2-Extraction and FTIR Characterization of Four Low-Rank Coals from China. 2011 International Conference on Materials for Renewable Energy \& Environment, Vol. 2, pp. 1607-1609.

https://doi.org/10.1109/ICMREE.2011.5930641 
[26] Sun, X., Sun, Y. and Yu, J. (2015) Leaching of Aluminum from Coal Spoil by Mechanothermal Activation. Frontiers of Chemical Science and Engineering, 9, 216-223. https://doi.org/10.1007/s11705-015-1518-2

[27] Reeves, J.B. (2012) Mid-Infrared Spectroscopy of Biochars and Spectral Similarities to Coal and Kerogens: What Are the Implications? Applied Spectroscopy, 66, 689695. https://doi.org/10.1366/11-06478

[28] Li, X., Ju, Y., Hou, Q., Li, Z. and Fan, J. (2012) FTIR and Raman Spectral Research on Metamorphism and Deformation of Coal. Journal of Geological Research, 2012, 8. https://doi.org/10.1155/2012/590857

[29] Guo Shaohui, L.S.Q.K. (2001) Structural Characterization of Chinese Coal Macerals by $13 \mathrm{C} \mathrm{nmr}$ and Ruthenium Ion Catalyzed Oxidation. Energy Sources, 23, 27-35. https://doi.org/10.1080/00908310151092092

[30] Retcofsky, H.L. and Friedel, R.A. (1970) The Potential of 13C NMR in Coal Research. In: Friedel, R.A., Ed., Spectrometry of Fuels, Springer US, Boston, MA, 99-119. https://doi.org/10.1007/978-1-4684-8121-1_8

[31] Sing, K.S.W. (1985) Reporting Physisorption Data for Gas/Solid Systems with Special Reference to the Determination of Surface Area and Porosity. IUPAC Commission on Colloid and Surface Chemistry Including Catalysis. Pure and Applied Chemistry, 57, 603-619. https://doi.org/10.1351/pac198557040603

[32] Sing, K.S.W. (1995) Physisorption of Nitrogen by Porous Materials. Journal of Porous Materials, 2, 5-8. https://doi.org/10.1007/BF00486564

[33] Gregg, S.J. and Sing, K.S.W. (1982) Adsorption, Surface Area, and Porosity. Academic Press, New York, London.

[34] Rafatullah, M., Sulaiman, O., Hashim, R. and Ahmad, A. (2010) Adsorption of Methylene Blue on Low-Cost Adsorbents: A Review. Journal of Hazardous Materials, 177, 70-80. https://doi.org/10.1016/j.jhazmat.2009.12.047

\section{Submit or recommend next manuscript to SCIRP and we will provide best} service for you:

Accepting pre-submission inquiries through Email, Facebook, LinkedIn, Twitter, etc. A wide selection of journals (inclusive of 9 subjects, more than 200 journals)

Providing 24-hour high-quality service

User-friendly online submission system

Fair and swift peer-review system

Efficient typesetting and proofreading procedure

Display of the result of downloads and visits, as well as the number of cited articles

Maximum dissemination of your research work

Submit your manuscript at: http://papersubmission.scirp.org/

Or contact msce@scirp.org 